
Transfusion Medicine
and Hemotherapy
Review Article - Übersichtsarbeit

Transfus Med Hemother 2005;32:97-100

DOI: $10.1159 / 000082780$
Received: December 11, 2004

Accepted: December 13, 2004

Communicated by D. Stahl

Published online: March 29, 2005

\title{
Pure Red Cell Aplasia Induced by Antibodies against Human Recombinant Erythropoietin
}

\author{
Anne Krüger Kai-Uwe Eckardt \\ Medizinische Klinik für Nephrologie und Hypertensiologie, Universitätsklinikum Erlangen und Klinikum Nürnberg, Friedrich-Alexander \\ Universität, Erlangen-Nürnberg, Germany
}

\author{
Key Words \\ Erythropoietin - Antibodies - Anemia · \\ Pure red cell aplasia
}

\section{Summary}

Human recombinant erythropoietin (epoetin) is a very effective and safe biopharmaceutical. However, in 1998 the incidence of pure red cell aplasia (PRCA) induced by antierythropoietin (anti-EPO) antibodies in patients treated with epoetin started to increase. PRCA is a rare condition of non-regenerative anemia which can be associated with a variety of diseases and is in some cases of immunological origin. To date the incidence rate of epoetininduced PRCA has fallen again. The temporary rise in incidence was associated with the subcutaneous use of the epoetin alpha preparation distributed outside the USA and followed a change in the formulation of this product to human serum albumin-free polysorbate 80. Among several reasons that have been explored, the most likely cause has been the contamination of the solution with organic compounds leaching from rubber stoppers of pre-filled syringes. The diagnosis of PRCA is based on typical clinical features, detection of anti-EPO antibodies and typical findings in bone marrow. In cases of suspected PRCA, epoetin medication needs to be discontinued immediately. Immunosuppressive treatment can be successful and should be initiated if possible once the diagnosis has been confirmed.

\author{
Schlüsselwörter \\ Erythropoetin · Antikörper · Anämie · \\ Pure red cell aplasia
}

\section{Zusammenfassung}

Humanes rekombinantes Erythropoetin (Epoetin) ist ein sehr effektives und nebenwirkungsarmes Biopharmakon. Seit 1998 wurde jedoch eine Zunahme der Inzidenz von Fällen mit "pure red cell aplasia» (PRCA) induziert durch Anti-Erythropoetin(anti-EPO)-Antikörper beobachtet. PRCA ist eine sehr seltene Form einer aregenerativen Anämie, die in Verbindung mit verschiedenen Erkrankungen vorkommen kann und in einigen Fällen immunologische Ursachen hat. Mittlerweile ist die Inzidenzrate der durch Epoetin induzierten PRCA wieder gefallen. Der temporäre Anstieg war assoziiert mit der subkutanen Applikation von außerhalb der USA vertriebenem Epoetin alpha und folgte einer Umstellung der Formulierung dieses Präparats auf eine Albumin-freie Polysorbat-80Lösung. Unter verschiedenen Ursachen, die in Betracht gezogen wurden, scheint eine Kontamination der Applikationslösung mit organischen Substanzen, die durch Polysorbat 80 aus dem Gummistopfen der Fertigspritzen herausgelöst wurden, am wahrscheinlichsten. Die Diagnose einer durch Epoetin induzierten PRCA stützt sich auf einen typischen klinischen Verlauf, den Nachweis von Anti-EPO-Antikörpern sowie typische Knochenmarkbefunde. Bei Verdacht auf PRCA sollte die Epoetin-Medikation sofort abgesetzt werden. Eine immunsuppressive Therapie kann erfolgreich sein und sollte, wenn möglich, begonnen werden, wenn die Diagnose bestätigt ist.

\begin{tabular}{ll}
\hline KARGER & @ 2005 S. Karger GmbH, Freiburg \\
$\begin{array}{l}\text { Fax +49 76145207 14 } \\
\begin{array}{l}\text { E-mail Information@Karger.de } \\
\text { www.karger.com }\end{array}\end{array}$ & $\begin{array}{l}\text { Accessible online at: } \\
\text { www.karger.com/tmh }\end{array}$
\end{tabular}




\section{Introduction}

Human recombinant erythropoietin (epoetin) is one of the most successful applications of molecular gene technology in the development of therapeutic agents. The potential of biopharmaceuticals in the treatment of diseases caused by a deficiency of a specific endogenous protein is well known although the risk of immunogenicity is recognized. The formulation of the therapeutic agents, a contamination during the production process or subtle differences in protein structure or glycosylation are factors that have been associated with immunogenicity. Different routes of application also account for a varying risk of antibody induction.

\section{Incidence of Epoetin-Induced Pure Red Cell Aplasia}

More than 15 years ago recombinant human epoetin was first available for therapeutic use. For more than a decade side effects were rarely seen and mostly associated with an excessive increase in hematocrit. Cases of antibody formation were observed only sporadically [1-3]. Since 1998 an increasing number of cases occurred in which pure red cell aplasia (PRCA) developed due to formation of neutralizing anti-erythropoietin (anti-EPO) antibodies. In 2002 Casadevall et al. [4] first published a series of 13 patients with renal failure, who had been treated with epoetin successfully before they developed severe, transfusion dependent non-regenerative anemia. They provided evidence that all of these patients had anti-EPO antibodies, and were able to demonstrate the neutralizing capacity of these antibodies. Bone marrow examination showed findings typical for PRCA.

To date probably around 250 cases of PRCA due to anti-EPO antibodies have been registered worldwide, and recently 191 cases could be retrieved from databases of the Federal Drug Administration and manufacturers [5]. Although, given the widespread use of epoetin worldwide, the overall incidence rate, even if it was the highest observed so far, has still been low, this phenomenon has received considerable attention and publicity.

\section{Diagnosis of Epoetin-Induced Pure Red Cell Aplasia}

PRCA is a rare cause of severe anemia. It is characterized by reduction of erythroid precursors to $<0.5 \%$ in an otherwise normocellular bone marrow. Consequently, reticulocyte counts are low $\left(<10,000 / \mathrm{mm}^{3}\right)$, and transfusion-dependent anemia develops. In adults, acquired PRCA can be associated with thymoma, lymphoproliferative diseases, or various autoimmune-related disorders. It can also be secondary to viral infections or therapy with certain pharmaceuticals [6]. About $50 \%$ of all cases are idiopathic, and an underlying cause cannot be identified. In many of these cases immunoglobulin $\mathrm{G}$
(IgG) antibodies or cytotoxic $\mathrm{T}$ lymphocytes are directed against erythroid precursors, and immunosuppresive treatment is successful $[7,8]$. Only in rare cases, antibodies against endogenous epoetin have been identified [9].

The diagnosis of epoetin-induced PRCA is based on typical clinical findings, the absence of erythroid precursors in bone marrow aspirate and the presence of anti-EPO antibodies. Typical clinical features include treatment with epoetin for at least 3 weeks, a progressive drop in hemoglobin concentration of approximately $0.1 \mathrm{~g} / \mathrm{dl} / \mathrm{day}$ or transfusion requirement of 1 unit of packed red cells per week, and reticulocyte counts $<10,000 / \mathrm{mm}^{3}$. Some patients have also developed allergic skin or even systemic reactions [10].

Immunoassays are the method most often used to detect antibodies. Unspecific binding and false-positive results form a problem, especially with the classical ELISA testing. The neutralizing capacity of anti-EPO antibodies can only be demonstrated in bioassays which are based on the incubation of patients' sera with erythroid precursors or an epoetin-dependent cell line $[9,10]$. To date, a standardized method for antibody testing does not exist. It is therefore preferable to perform testing in a laboratory with special expertise in anti-EPO antibody testing.

\section{Possible Reasons for Epoetin-Induced Pure Red Cell Aplasia}

One of the risk factors for development of epoetin-induced PRCA is the subcutaneous (s.c.) route of application [10,11]. Probably all patients identified worldwide who suffer from anti-EPO antibody-induced PRCA have been treated with s.c. epoetin [6, 10-12]. In addition there are important differences between the different brands of epoetin. The number of cases reported in association with the use of the epoetin alpha preparation distributed outside the USA $\left(\right.$ Eprex $\left.^{\circledR}\right)$ is much higher than with any other epoetin $[5,13]$. Moreover, the temporary rise in incidence rates between 1998 and 2002 was due to cases associated with the use of this brand. However, cases have been observed with epoetin beta (NeoRecormon $\left.{ }^{\circledR}\right)[5$, 14] and the US preparation of epoetin alpha $\left(\right.$ Procrit $\left.^{\circledR}\right)$ [5]. To date no reports exist on PRCA in association with darbepoietin (Aranesp ${ }^{\circledR}$ ), a hyperglycosylated epoetin analogue, although rarely allergic reactions such as rash or urticaria have been observed under darbepoietin [12].

The higher risk of immunogenicity of one epoetin formulation has been subject of extensive investigations. The increase in incidence of PRCA coincides with the replacement of the stabilizing agent human serum albumin (HSA) by polysorbate 80 and glycine in order to comply with new European regulations. In the USA where the incidence of PRCA remained very low, HSA is still contained in the epoetin alpha preparation.

However, how this change in the formulation of epoetin alpha might have increased its immunogenicity remained obscure 
for some time. Polysorbate 80 itself is not known to directly effect immune reactions, and other epoetin preparations also contain this detergent albeit at different concentrations. According to information provided by the manufacturer, there has been no evidence for irregularities in the manufacturing process and the epoetin alpha molecule [15]. Neither aggregate formation nor increased rates of oxidization have been observed. Some investigators pointed out that high concentrations of polysorbate form micelles. They suggested that epoetin molecules might form macrostructures with these micelles and are thereby presented to immune cells at a regular spacial configuration, which increases the immune recognition [16]. The most likely explanation, however, is based on the recent finding of previously undetected compounds in the HPLC elution profile of Eprex syringes [15]. These additional compounds turned out to be organics which had been leached from the uncoated rubber syringe stopper by the action of polysorbate 80 . When pre-filled syringes of epoetin alpha were introduced in 1994, uncoated rubber stoppers were standard. Since then, subsequently Fluorotec-coated stoppers have come into use, and no leachates are detectable in syringes with covered stoppers. Moreover, leachates are only detectable when the detergent polysorbate 80 is in contact with uncoated rubber stoppers, and not when an HSA formulation is used in combination with rubber stoppers. Overall, the presence of these organic leachates coincides both with the temporal change in PRCA incidence as well as with differences between products. It is assumed that through mechanisms that are still poorly understood these compounds act as an immunological adjuvant in vivo and thereby lead to a higher rate of antibody formation [15]. Moreover, their concentration depends on storage and handling conditions, which could explain marked regional differences in PRCA incidence rates observed during recent years.

The vast majority of PRCA cases has been observed in patients with chronic kidney disease although patients suffering from anemia due to malignant diseases are also frequently treated with epoetin. Recently PRCA was diagnosed in 2 patients with myelodysplastic syndrome who had been treated with an epoetin preparation [12]. To date other cases of epoetin-induced PRCA have not been published in patients with malignant diseases. Unspecific immunosuppression in these patients due to the underlying disease or the specific therapy may be a reason for lower incidence as well as the shorter duration of therapy. In addition, pre-filled syringes with higher doses of epoetin alpha, which are more frequently used in cancer patients, have already had a coated rubber stopper for several years. The diagnosis may also be more difficult in cancer patients since many causes of anemia are common under these circumstances.

\section{Therapy of Pure Red Cell Anemia}

Once epoetin-induced PRCA is suspected, epoetin medication needs to be withdrawn immediately. It is important not to continue treatment with a different preparation because antibodies identified to date cross-react with all epoetin preparations as well as with endogenous epoetin.

Immunosuppressive treatment may be successful and should be initiated once the diagnosis is confirmed by positive antibody testing and bone marrow examination. Different immunosuppressive regimens, including corticosteroids, cyclophosphamide, cyclosporine, high-dose immunoglobulins and plasmapheresis, have been employed with varying therapeutic efficacy. Stopping epoetin therapy alone without immunosuppresive therapy so far only in rare cases has been found to improve anemia. Therefore, specific treatment is recommended if possible and tolerated. Renal transplantation has been performed successfully in PRCA patients and has immediately reversed clinical symptoms. This effect is probably attributable to immunosuppressive medication as well. To date there is no evidence that graft-derived epoetin enhances the immune response [17]

Screening for anti-EPO antibodies in asymptomatic patients is not recommended since no clinical consequences arise and false-positive results are to be expected. In patients with newly diagnosed anemia under therapy with epoetin, reticulocyte counts are an important measure for differential diagnosis. Once low reticulocyte counts have been measured, PRCA has to be suspected, and antibody testing as well as bone marrow examination should be performed.

\section{Prevention of Epoetin-Induced Pure Red Cell Aplasia}

Risk mitigation strategies undertaken after the sharp rise in PRCA incidence in 1998 included improved cold-chain management and a recommendation to switch to intravenous (i.v.) use of the epoetin alpha preparation associated with this rise. In 2002 the European authorities issued a contraindication for the s.c. use of this preparation in patients with chronic kidney disease. The manufacturers of other epoetin preparations, namely epoetin beta and darbepoetin, have not been required to change the indications of these products. In addition, as of April 2003 all epoetin alpha pre-filled syringes with the polysorbate 80-based formulation have been shipped with Fluorotec-coated stoppers that do not release any leachates. Altogether these measures have led to a sharp decline in incidence rates to the level observed before 1998 [5]. Based on the evidence that the use of coated stoppers avoids the leachates, which are the likely cause of the temporary increase in immunogenicity, the manufacturer has recently applied for re-approval of the s.c. application.

Many patients, including those with kidney disease not yet on dialysis, peritoneal dialysis patients and cancer patients, re- 
quire s.c. application of epoetin to benefit from its positive effects on quality of life and co-morbidities. Whether epoetin should be used i.v., if feasible, as in patients on dialysis to further reduce or basically avoid the very low risk that pertains with s.c. application, is controversial since the dose requirements are lower when the drug is given s.c. In any way physicians treating patients with epoetin need to be aware of the symptoms of this possible complication and necessary diagnostic and therapeutic measures.
The recent PRCA experience also has more general implications for the use of biotherapeutics since it exemplifies that 'minor' changes in the production process may have significant consequences and that storing and handling conditions may be more relevant than frequently assumed in clinical practice. The risk of immunogenicity will also have to be considered for second generation and generic biotherapeutics under development, including generic epoetins.

\section{References}

1 Peschle C, Marmont AM, Marone G, Genovese A, Sasso GF, Condorelli M: Pure red cell aplasia: Studies on an IgG serum inhibitor neutralizing erythropoietin. Br J Haematol 1975;30:411-417.

2 Peces R, de la Torre TM, Alcazar R, Urra JM: Antibodies against recombinant human erythropoietin in a patient with erythropoietin-resistant anemia. N Engl J Med 1996;335:523-524.

3 Prabhakar SS, Muhlfelder T: Antibodies to recombinant human erythropoietin causing pure red cell aplasia. Clin Nephrol 1997;47:331-335.

4 Casadevall N, Nataf J, Viron B, Kolta A, Kiladjian JJ, Martin-Dupont P, Michaud P, Papo T, Ugo V, Teyssandier I, Varet B, Mayeux P: Pure red-cell aplasia and anti-erythropoietin antibodies in patients treated with recombinant erythropoietin. $\mathrm{N}$ Engl J Med 2002;346:469-475.

5 Bennett CL, Luminari S, Nissenson AR, Tallman MS, Klinge SA, McWilliams N, McKoy JM, Kim B, Lyons EA, Trifilio SM, Raisch DW, Evens AM, Kuzel TM, Schumock GT, Belknap SM, Locatelli F, Rossert J, Casadevall N: Pure red-cell aplasia and epoetin therapy. N Engl J Med 2004;351:1403-1408.
6 Dessypris EN: The biology of pure red cell aplasia. Semin Hematol 1991;28:275-284.

7 Fisch P, Handgretinger R, Schaefer HE: Pure red cell aplasia. Br J Haematol 2000;111:1010-1022.

8 Casadevall N: Pure red cell aplasia and anti-erythropoietin antibodies in patients treated with epoetin. Nephrol Dial Transplant 2003;18(suppl 8): VIII37-VIII41.

9 Casadevall N, Dupuy E, Molho-Sabatier P, Tobelem G, Varet B, Mayeux P: Autoantibodies against erythropoietin in a patient with pure red-cell aplasia. $\mathrm{N}$ Engl J Med 1996;334:630-633.

10 Rossert J, Casadevall N, Eckardt KU: Anti-erythropoietin antibodies and pure red cell aplasia. J Am Soc Nephrol 2004;15:398-406.

11 Schellekens H: Immunogenicity of therapeutic proteins. Nephrol Dial Transplant 2003;18:1257-1259.

12 Eckardt KU, Casadevall N: Pure red-cell aplasia due to anti-erythropoietin antibodies. Nephrol Dial Transplant 2003;18:865-869.
13 Gershon SK, Luksenburg H, Cote TR, Braun MM Pure red-cell aplasia and recombinant erythropoietin. N Engl J Med 2002; 346:1584-1586.

14 Krüger A, Schröer W, Röhrs F, Vescio G: PRCA in a patient treated with epoetin beta. Nephrol Dial Transplant 2003;18:1033-1034.

15 Sharma B, Bader F, Templeman T, Lisi P, Ryan M, Heavner G: Technical investigations into the cause of the increased incidence of antibody-mediated pure red cell aplasia associated with Eprex ${ }^{\circledR}$. (sponsored article) Eur J Hosp Pharmacy 2004;5: 86-91.

16 Hermeling S, Schellekens H, Crommelin DJ, Jiskoot W: Micelle-associated protein in epoetin formulations: A risk factor for immunogenicity? Pharm Res 2003;20:1903-1907.

17 Verhelst D, Rossert J, Casadevall N, Krüger A, Eckardt K-U, Macdougall IC: Treatment of erythropoietin-induced pure red cell aplasia: a retrospective study. Lancet 2004;363:1768-1771. 